\title{
ANALISIS AKURASI MODEL-MODEL PREDIKSI FINANCIAL DISTRESS
}

\author{
Inggar Nur Arini \\ Universitas Negeri Surabaya \\ inggar.17080574125@mhs.unesa.ac.id
}

\begin{abstract}
This study aims to find the most accurate predictor model of financial distress. The company has the potential to go bankrupt. Bankruptcy can be predicted using an accurate predictor model as an early warning to anticipate financial distress. This research was conducted on the global retail industry which is included in Kantar's 2019 Top 30 Global Retails (EUR). The data in this study were taken from 60 annual reports for the 2018-2019 period and a sample of 30 on global retail companies. The accuracy rate is calculated by the number of correct predictions divided by the total data and multiplied by one hundred percent. This study compares four predictor models of financial distress, namely the Altman model, the Springate model, the Taffler model, and the Grover model. With the results of the study, the Grover model has the highest level of accuracy, which is $76.67 \%$.
\end{abstract}

Keywords : altman model; financial distress; grover model; springate model; taffler model.

\section{PENDAHULUAN}

Pada tahun 2018, situs bisnis inc.5000 merilis "The 10 Hottest Industries for Startups in 2018”. Dari sudut pandang lain, Deloitte merupakan organisasi terhimpun dari puluhan ribu profesional untuk memberikan audit dan asuransi, konsultasi, risiko dan penasihat keuangan, manajemen risiko, pajak, dan layanan menilai bahwa tahun 2019 merupakan tahun transisi, industri retail kemungkinan akan mengalami resesi seperti persaingan harga, sehingga industri retail harus menyesuaikan terhadap pasar, sebagai tindakan preventif sebelum mengalami downturn. Kim (2020) mengungkapkan bahwa 17 retail besar mengalami kebangkrutan, hal tersebut dapat diambil sebagai contoh bahwa perusahaan retail yang sudah berkecimpung selama 60 tahun seperti Century 21 yang memiliki 13 store di 4 negara dan bahkan sudah memiliki e-commerce sendiri tetap mengalami kebangkrutan (Kim, 2020). Kantar adalah agensi yang bergerak dibidang statistik data merilis 30 perusahaan retail terbesar di dunia berdasarkan analisis atas laporan keuangan terhadap perusahaan yang termasuk industri retail. Dalam dua tahun berturut perilisan 30 perusahaan retail terbesar di dunia selama tahun 2018-2019 posisi beberapa perusahaan mengalami fluktuasi. Dari fenomena tersebut, dapat dikatakan bahwa perusahaan yang telah lama beroperasi maupun yang termasuk perusahaan besar hingga membuatnya terperingkat sebagai perusahaan teratas dunia tetap berisiko mengalami risiko financial distress hingga kebangkrutan (Gunawan et al., 2017). Financial distress ialah situasi kesulitan keuangan yang ada di perusahaan, di mana setiap perusahaan pasti menghindari terjadinya financial distress (Susanti, 2016).

Menurut kacamata investor, perlu dilakukan analisis bisnis terkait nilai saham, reputasi, dan prospek bisnis dari perusahaan tersebut agar menghindar dari capital lost. Analisis harus dilakukan sejak dini karena pihak eksternal salah satunya investor menjadi penerima risiko terbesar, jika perusahaan mengalami financial distress (Vestari \& Farida, 2014). Analisis untuk memprediksi financial distress digunakan sebagai Early Warning System (EWS) bagi pihak eksternal sebagai alarm kondisi perusahaan tersebut.

Terdapat beberapa model prediksi financial distress dan dikembangkan oleh beberapa peneliti. Beberapa peneliti banyak mengembangkan model Altman dengan menambah atau mengurangkan variabel (rasio keuangan) yang telah dipilih Altman. Model prediksi yang termasuk jenis Model Discriminant Analysis (MDA) adalah Springate, Taffler, dan Grover. Setiap model prediksi financial distress menghasilkan tingkat akurasi yang berbeda-beda (Sari, 2016); (Priyanti, 2019); Kartikasari \& Hariyani (2019); dan (Hungan \& Sawitri, 2018). 
Model prediksi Altman 1968 menggunakan rasio keuangan antara lain, penjualan, nilai buku keseluruhan hutang, hasil pasar saham, modal kerja, laba sebelum bunga maupun pajak, laba ditahan, dan keseluruhan asset (Priyanti, 2019). Penelitian terdahulu menunjukkan tingkat akurasi model prediksi Altman yang bervariasi antara lain 92\% (Sari, 2016); 91,66\% (Meiliawati \& Isharijadi, 2017); 82,5\% (Tan \& Wibisana, 2020); 81,81\% (Priyanti, 2019); 80\% (Putri, 2018); 67,2\% (Huda, 2017); 66,67\% (Komarudin et al., 2019); 65,52\% (Primasari, 2018); 60\% (Rahayu et al., 2016); 58,33\% (Andrianti, 2016); 58,3\% (Najib \& Cahyaningdyah, 2020); 45,45\% (Ratri, 2020); 36,36\% (Colline, 2020); 21,93\% (Bilondatu et al., 2019); 20\% (Azizah, 2019); Winaya et al., 2020); 8,10\% (Ick \& Tarigan, 2018).

Model prediksi Springate 1978 awalnya terdiri dari 19 rasio keuangan dan dilakukan uji oleh Altman akhirnya menggunakan empat rasio untuk menguji perusahaan bangkrut dan tidak bangkrut. Rasio keuangan yang dipakai adalah modal kerja, keseluruhan aset, laba bersih sebelum pajak bunga, kewajiban lancar, dan penjualan (Huda, 2017). Penelitian terdahulu menunjukkan tingkat akurasi model prediksi Springate yang berbeda-beda antara lain 100\% (Priyanti, 2019); 92,7\% (Huda, 2017); 91,66\% (Meiliawati \& Isharijadi, 2017); 80\% (Rahayu et al., 2016); 77\% (Sari, 2016); 67\% (Hungan \& Sawitri, 2018); 66,67\% (Andrianti, 2016); 65,09\% (Primasari, 2018); 48,72\% (Komarudin et al., 2019); 33,41\% (Bilondatu et al., 2019); 31,81\% (Ratri, 2020); 30,9\% (Tan \& Wibisana, 2020); 22,22\% (Azizah, 2019); 18,18\% (Colline, 2020); -9,23\% (Ick \& Tarigan, 2018).

Metode Taffler 1983 merupakan model analisis yang menghitung lebih dari 80 rasio yang dipilih dari akun perusahaan industri yang mengalami kebangkrutan pada periode 1968 sampai 1976. Terpilih 46 perusahaan industri yang berhasil dianalisis (Agarwal \& Taffler, 2007). Kartikasari \& Hariyani (2019) menyatakan tingkat akurasi metode Taffler sebesar $30 \%$.

Metode Grover 2003 adalah model dengan desain dan dilakukan penilaian ulang terhadap model Altman. Model ini menggunakan sampel 70 perusahaan, dimana 35 perusahaan terjadi kebangkrutan maupun 35 korporasi sehat periode 1982 hingga 1996. Model prediksi ini menggunakan rasio seperti, modal kerja, keseluruhan aset, penghasilan sebelum bunga dan pajak (Parquinda \& Azizah, 2019). Penelitian terdahulu menunjukkan tingkat akurasi model prediksi Grover yang berbeda-beda antara lain 78\% (Hungan \& Sawitri, 2018); 72,22\% (Azizah, 2019); 64,10\% (Komarudin et al., 2019); 51,72\% (Primasari, 2018); 41,46\% (Andrianti, 2016); 27,27\% (Ratri, 2020); 0,46\% (Ick \& Tarigan, 2018).

Berdasarkan pemaparan fenomena dan kondisi tersebut, penelitian terkait analisis akurasi modelmodel prediksi financial distress dilakukan terhadap perusahaan retail yang termasuk dalam Kantar's 2019 Top 30 Global Retails (EUR). Penelitian ini bertujuan selain untuk mengetahui tingkat akurasi model prediksi financial distress, juga untuk mengetahui apakah perusahaan retail yang tergolong The World's biggest Companies juga mengalami financial distress.

\section{KAJIAN PUSTAKA DAN PENGEMBANGAN HIPOTESIS}

\section{Financial distress}

Kebangkrutan berawal dari kesulitan keuangan yaitu keadaan perusahaan yang tidak bisa membayar sesuai perjanjiannya pada saat jatuh tempo, sehingga perusahaan mengalami kebangkrutan (Munawir, 2007). Kebangkrutan muncul karena beberapa faktor yaitu, manajemen yang kurang mampu untuk mengoperasikan perusahaan, ketidakseimbangan pengalaman antara produksi, fungsi-fungsi lain pada korporasi dan keuangan, kurangnya pengalaman manajerial dan operasional (Hanafi, 2010).

\section{Model Prediksi Financial distress}

Konsep dari prediksi financial distress dengan MDA merupakan kombinasi dari financial ratio menjadi suatu model prediksi menggunakan analisis diskriminan. Selain model Altman Z Score, terdapat beberapa model MDA yang populer seperti Springate, Taffler, dan Grover. Penelitian ini membandingkan empat model prediksi financial distress yang termasuk dalam model MDA. 
Ada bermacam riset perihal akurasi prediksi financial distress yang pernah dilaksanakan terdahulu sebagaimana Tan \& Wibisana (2020), Azizah (2019), Najib \& Cahyaningdyah (2020), Kartikasari \& Hariyani (2019), Arasu et al. (2013), Taffler (2007). Namun semua hasil penelitian menunjukkan hasil yang berbeda, artinya terdapat inkonsistensi dalam menentukan model prediksi yang paling akurat.

H1: Model prediksi yang paling akurat dalam memprediksi financial distress pada perusahaan yang termasuk Kantar's 2019 Top 30 Global Retails (EUR) adalah Model Grover.

\section{METODE PENELITIAN}

Langkah pertama untuk menentukan keakuratan model prediksi financial distress yaitu menentukan tingkat akurasi model prediksi. Penelitian ini membandingkan empat model prediksi yaitu Altman Z Score, Springate, Taffler, dan Grover. Setiap model prediksi menghitung seluruh sampel yang ada dengan formula perhitungan pada masing-masing model. Model prediksi Altman Z Score pada formula (1).

$Z=6,56 X 1+3,26 \times 2+6,72 \times 3+1,05 X 4$

Keterangan :

$\mathrm{X} 1=$ working capital/total asset

$\mathrm{X} 2$ = retained earnings $/$ total asset

$\mathrm{X} 3$ = earning before interest and taxes/total asset

$\mathrm{X} 4=$ book value of equity/book value of total liabilities

Rumus (1) model prediksi Altman Z Score merujuk dari penelitian (Winaya et al., 2020). Jika nilai Z Score $>$ 2,6 maka korporasi dapat dikatakan sehat, $\mathrm{Z}$ Score $1,1<\mathrm{Z}<2,6$ maka korporasi ada di grey area, Z Score $<1,1$ maka korporasi mengalami financial distress. Rumus (2) model prediksi Springate.

$\mathrm{S}=1,03 \mathrm{X} 1+3,07 \mathrm{X} 2+0,66 \mathrm{X} 3+0,4 \mathrm{X} 4$

Keterangan:

$\mathrm{X} 1=$ Working Capital/ Total Assets

$\mathrm{X} 2=$ Net Profit Before Interest Taxes/ Total Assets

X3 = Net Profit Before Taxes/Current Liability

$\mathrm{X} 4=$ Sales $/$ Total Assets

Rumus (2) model prediksi Springate merujuk dari penelitian (Huda, 2017). Jika nilai S Score> 0,82 maka korporasi pada keadaan sehat, $\mathrm{S}$ Score $<0,82$ maka korporasi mengalami financial distress. Rumus (3) model prediksi Taffler.

Z-Taffler $=3,20+12,18 \mathrm{X} 1+2,50 \mathrm{X} 2-10,68 \mathrm{X} 3+0,0289 \mathrm{X} 4$

Keterangan:

$\mathrm{X} 1=$ EBT/ Current Liabitities

$\mathrm{X} 2=$ Current Assets/ Total Liabilities

$\mathrm{X} 3=$ Current Liabilities/ Total Assets

$\mathrm{X} 4=($ Quick Assets - Current Liabilities $) /(($ Sales - PBT - Depreciation $) / 365)$

Rumus (3) model prediksi Taffler merujuk dari penelitian (Agarwal \& Taffler, 2007). Jika nilai Z>0 maka korporasi pada keadaan sehat, $\mathrm{Z}<0$ hingga korporasi mengalami financial distress. Rumus (4) model prediksi Grover.

$\mathrm{G}-\mathrm{Score}=1,650(\mathrm{X} 1)+3,404(\mathrm{X} 3)-0,016(\mathrm{ROA})+0,057$ 


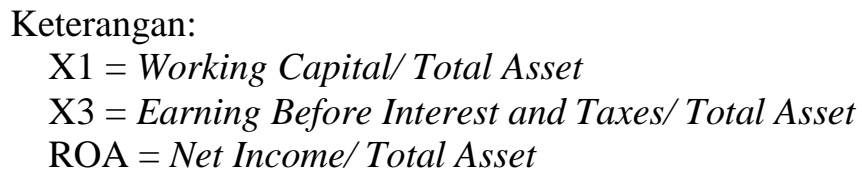

Rumus (4) model prediksi Grover merujuk dari penelitian (Parquinda \& Azizah, 2019). Jika nilai G Score> 0,01 maka korporasi pada keadaan sehat, $G$ Score $<-0,02$ maka perusahaan mengalami financial distress.

Analisi keakuratan model prediksi ditentukan atas dasar perhitungan estimasi yang benar antara hasil prediksi terhadap realita perusahaan. Realita perusahaan didasarkan pada perusahaan yang delisting dari bursa. Tingkat akurasi setiap model dihitung menggunakan rumus (5).

Tingkat Akurasi $=\frac{\text { Jumlah prediksi benar }}{\text { Jumlah sampel }} \times 100 \%$

Model prediksi paling akurat merupakan model dengan persentase tingkat akurasi prediksi paling tinggi atau paling mendekati 100\%. Dilakukan robustness check untuk melihat bagaimana hasil akhir apabila asumsi berubah dan menguji bahwa hasil analisis utama baik-baik saja (Gelman, 2017). Analisis keakuratan model prediksi ditentukan atas dasar perhitungan estimasi yang benar antara hasil model prediksi terhadap hasil interest conerage ratio. Perusahaan mengalami financial distress jika tingkat ICR< 1 (Claessens et al., 2003).

\section{HASIL DAN PEMBAHASAN}

\section{Deskripsi Data}

Masing-masing perusahaan akan diamati dari last trading. Last trading menunjukkan bahwa perusahaan masih aktif dan tidak delisting dari bursa. Selain itu, perusahaan juga akan diamati setelah satu tahun prediksi apakah perusahaan tersebut telah merger atau diakuisisi dengan perusahaan lain atau tidak. Hal ini bertujuan untuk menganalisis dan membandingkan hasil prediksi dari masingmasing model prediksi dengan realita perusahaan saat ini. Pada waktu pengamatan last trading perusahaan dilakukan tanggal 10 Juni 2021 pada setiap bursa efek. Selain melihat realita kondisi perusahaan, interest coverage ratio juga diperhitungkan untuk analisis robustness check.

\section{Tingkat Akurasi}

Penentuan tingkat akurasi model prediksi dalam penelitian ini didasarkan pada persentase tingkat akurasi dari masing-masing model prediksi yang dihitung menggunakan rumus (5). Hasil persentase diperoleh dari perbandingan hasil prediksi masing-masing model dibandingkan dengan realita perusahaan setelah tahun prediksi. Model prediksi dengan persentase tingkat akurasi paling mendekati $100 \%$ menunjukkan estimasi paling akurat dalam mengestimasikan financial distress korporasi yang berpotensi bangkrut di masa mendatang.

Tabel 1.

TINGKAT AKURASI BERDASARKAN REALITA

\begin{tabular}{lccr}
\hline Model Prediksi & Prediksi Benar & Jumlah Sampel & Tingkat Akurasi \\
\hline Grover & 46 & 60 & $76,67 \%$ \\
Altman & 43 & 60 & $71,67 \%$ \\
Springate & 42 & 60 & $70 \%$ \\
Taffler & 43 & 60 & $71,67 \%$ \\
\hline Sumber: Rekap hasil perhitungan pada excel
\end{tabular}


Tabel 1 model prediksi paling akurat dalam memprediksi realita perusahaan yaitu model prediksi Grover dengan tingkat akurasi tertinggi sebesar 76,67\%, diikuti model Altman dan model Taffler di mana keduanya memiliki tingkat akurasi $71,67 \%$, dan model Springate dengan tingkat akurasi $70 \%$.

Tabel 2.

KONDISI REALITA PERUSAHAAN

\begin{tabular}{|c|c|c|c|c|}
\hline $\begin{array}{c}\text { Nama } \\
\text { Perusahaan }\end{array}$ & $\begin{array}{c}\text { Bursa } \\
\text { Efek }\end{array}$ & $\begin{array}{c}\text { Last } \\
\text { Trading }\end{array}$ & Keterangan & $\begin{array}{c}\text { Tgl } \\
\text { Pencarian }\end{array}$ \\
\hline Adeka & TSE & $04 / 06 / 2021$ & Listing & $10 / 06 / 2021$ \\
\hline Aeon & TSE & 01/06/2021 & Listing & $10 / 06 / 2021$ \\
\hline Ahold Delhaize & LSE & $11 / 06 / 2021$ & Listing & $10 / 06 / 2021$ \\
\hline Casino & LSE & $11 / 06 / 2021$ & Listing & $10 / 06 / 2021$ \\
\hline Amazon & NASDAQ & $11 / 06 / 2021$ & Listing & $10 / 06 / 2021$ \\
\hline Auchan & LSE & $14 / 10 / 2016$ & Delisting & $10 / 06 / 2021$ \\
\hline Walmart & NYSE & $10 / 06 / 2021$ & Listing & $10 / 06 / 2021$ \\
\hline Carrefour & ENX & $10 / 06 / 2021$ & Listing & $10 / 06 / 2021$ \\
\hline $\mathrm{X} 5$ & LSE & $11 / 06 / 2021$ & Listing & $10 / 06 / 2021$ \\
\hline Ceconomy & FWB & $11 / 06 / 2021$ & Listing & $10 / 06 / 2021$ \\
\hline China Resource & HKEX & $11 / 06 / 2021$ & Listing & $10 / 06 / 2021$ \\
\hline Coles & ASX & $21 / 11 / 2018$ & Listing & $10 / 06 / 2021$ \\
\hline Costo & NYSE & $10 / 06 / 2021$ & Listing & $10 / 06 / 2021$ \\
\hline Dollar G & NYSE & $10 / 06 / 2021$ & Listing & $10 / 06 / 2021$ \\
\hline Family Mart & LSE & 2020 & Delisting & $10 / 06 / 2021$ \\
\hline $\mathrm{HM}$ & TSE & $06 / 05 / 2021$ & Listing & $10 / 06 / 2021$ \\
\hline Home Depot & NYSE & $10 / 06 / 2021$ & Listing & $10 / 06 / 2021$ \\
\hline Inter IKEA & NASDAQ & $24 / 03 / 2021$ & Listing & $10 / 06 / 2021$ \\
\hline Kroger & NYSE & $10 / 06 / 2021$ & Listing & $10 / 06 / 2021$ \\
\hline Loblaw & TMX & $10 / 06 / 2021$ & Listing & $10 / 06 / 2021$ \\
\hline Tesco & LSE & $11 / 06 / 2021$ & Listing & $10 / 06 / 2021$ \\
\hline Macys & NYSE & $10 / 06 / 2021$ & Listing & $10 / 06 / 2021$ \\
\hline Sains Bury's & LSE & $11 / 06 / 2021$ & Listing & $10 / 06 / 2021$ \\
\hline Suning & TSE & 2018 & Delisting & $10 / 06 / 2021$ \\
\hline AAPL (Appel) & NASDAQ & $10 / 06 / 2021$ & Listing & $10 / 06 / 2021$ \\
\hline TJX & NYSE & $10 / 06 / 2021$ & Listing & $10 / 06 / 2021$ \\
\hline Lawson & TSE & $26 / 05 / 2021$ & Listing & $10 / 06 / 2021$ \\
\hline WBA & NASDAQ & $10 / 06 / 2021$ & Listing & $10 / 06 / 2021$ \\
\hline CVS & NYSE & $10 / 06 / 2021$ & Listing & $10 / 06 / 2021$ \\
\hline Rewe & FWB & $10 / 06 / 2021$ & Listing & $10 / 06 / 2021$ \\
\hline
\end{tabular}

Sumber: Rekap data sampel pada bursa efek

Tabel 2 menunjukkan kondisi realita perusahaan sampel. Terdapat 30 perusahaan yang berasal dari sembilan bursa yang berbeda. Keseluruhan data perusahaan diakses di tanggal yang sama yaitu 10 Juni 2021 untuk melihat data last trading. Dari 30 perusahaan tersebut diketahui tiga perusahaan saat diakses telah berstatus delisting.

Berdasarkan uji Robustness check pada tabel 3, tingkat akurasi tertinggi yaitu model Grover sebesar 78.67\%; model Altman 73.33\%; model Springate 70\%; dan model Taffler tingkat akurasi sebesar $70 \%$. 
Tabel 3.

ROBUSTNESS CHECK

\begin{tabular}{lccr}
\hline Model Prediksi & Prediksi Benar & Jumlah Sampel & Tingkat Akurasi \\
\hline Grover & 46 & 60 & $76,67 \%$ \\
Altman & 44 & 60 & $73,33 \%$ \\
Springate & 42 & 60 & $70 \%$ \\
Taffler & 42 & 60 & $70 \%$ \\
\hline
\end{tabular}

Sumber: Rekap hasil perhitungan pada excel

Model prediksi yang paling akurat dalam memprediksi financial distress pada perusahaan yang termasuk Kantar's 2019 Top 30 Global Retails (EUR)

Robustness check berdasarkan perbandingan model prediksi dengan interest coverage ratio membuktikan model prediksi Grover memiliki tingkat akurasi terbaik sudah benar maupun akurat. Model Grover dapat memprediksi tahun 2018 sebanyak 23 perusahaan, tahun 2019 sebanyak 23 perusahaan dengan total 46 prediksi benar dari 60 jumlah sampel. Ada beberapa rasio keuangan yang perlu diperhatikan yaitu, working capital, total aset, EBIT, dan net income karena rasio tersebut paling mampu menjelaskan kondisi financial distress.

Menurut Zebua \& Purnomo (2020) model prediksi Grover paling akurat dalam memprediksi kebangkrutan perusahaan karena model prediksi Grover menggunakan rasio keuangan yang memperhatikan seberapa efektif perusahaan dalam memeroleh laba dari aset yang dimiliki. Hastuti (2018) juga mendukung hasil robustness check bahwa memprediksi financial distress dengan tingkat akurasi paling tinggi dihasilkan oleh model prediksi Grover dengan tingkat akurasi sebesar 76,67\%. Sedangkan model Altman memiliki tingkat akurasi sebesar 73,33\%, kemudian model Springate dan model Taffler keduanya dengan tingkat akurasi sejumlah $70 \%$.

\section{KESIMPULAN}

Hasil analisis dan perhitungan menyimpulkan tingkat akurasi model prediksi financial distress paling akurat pada perusahaan retail yang termasuk dalam Kantar's 2019 Top 30 Global Retails (EUR) adalah model Grover yang menghasilkan tingkat akurasi sebesar 76,67\%. Jika dibandingkan dengan model Altman dengan tingkat akurasi 71,67\%, model Springate dengan tingkat akurasi sebesar 70\%, dan model Taffler dengan tingkat akurasi sebesar 71,67\%. Dari perhitungan dan analisis tersebut perlu adanya uji ketahanan dengan melakukan robustness check. Uji robustness check membuktikan bahwa hasil prediksi yang dilakukan oleh model Grover yaitu model prediksi paling tinggi tingkat akurasinya adalah benar. Setelah dilakukan uji robustness check hasil persentase tingkat akurasi dari model Grover menghasilkan nilai yang sama, ini dapat diartikan bahwa model Grover tetap menjadi model prediksi dengan tingkat akurasi tertinggi dibandingkan model Altman, model Springate, dan model Taffler. Maka dari itu, model Grover dapat disimpulkan sebagai model paling akurat dalam memprediksi financial distress di antara empat model prediksi tersebut, dengan batasan ruang lingkup yang menjadi subjek penelitian adalah perusahaan di bidang retail.

Implikasi ini dapat membantu perusahaan dalam memahami analisis prediksi financial distress dan dapat mengambil keputusan jika perusahaan mengalami kesulitan keuangan atau bahkan terjadi kebangkrutan. Bagi investor, dapat digunakan untuk membantu melihat potensi financial distress pada suatu perusahaan dan sebagai bahan pertimbangan sebelum melakukan investasi sehingga keputusan investasi yang akan dilakukan semakin baik.

Penelitian selanjutnya dapat melakukan penelitian pada perusahaan dengan sektor berbeda, namun perusahaan tersebut terdaftar dalam perusahaan terbaik dunia dan disarankan untuk mengembangkan model prediksi financial distress, tidak hanya melakukan analisis akurasi saja. Bagi Investor yang akan melakukan investasi pada suatu perusahaan harus mengetahui keberlangsungan usaha 
perusahaan, untuk mengetahui potensi kebangkrutan perusahaan yaitu dengan menggunakan model Grover.

\section{DAFTAR PUSTAKA}

Agarwal, V., \& Taffler, R. (2007). Twenty Five Years Of The Taffler Z-Score Model Does It Really Have Predictive Ability. Accounting and Business Research, 37(4), 285-300.

Andrianti. (2016). Analisis Ketepatan Model Altman, Springate, Zmijewski, Ohlson, dan Grover sebagai Detektor Kebangkrutan. Jurnal Ilmu \& Riset Manajemen, 36-37.

Arasu, R., Balaji, C. D., Kumar, P., \& Thamizhselvi, N. (2013). Applicability of Fulmer and Springate Models for Predicting Financial Distress of Firms in the Finance Sector - an Empirical Analysis. Elk Asia, 4(2), 1-27. https://doi.org/10.16962/EAPJFRM/issn.2349$2325 / 2014$

Bilondatu, D. N., Dungga, M. F., \& Selvi, S. (2019). Analisis Model Altman Z-Score, Springate, dan Zmijewski sebagai Metode dalam Memprediksi Kondisi Kebangkrutan pada PT. Garuda Indonesia, Tbk periode 2014-2018. JAMIN : Jurnal Aplikasi Manajemen dan Inovasi Bisnis, 2(1), 40. https://doi.org/10.47201/jamin.v2i1.35

Claessens, S., Djankov, S., \& Klapper, L. (2003). Resolution of Corporate Distress in East Asia. Journal of Empirical Finance, 10(1-2), 199-216. https://doi.org/10.1016/S09275398(02)00023-3

Colline, F. (2020). Bankruptcy Prediction Analysis: a Case Study of Retail Companies in Indonesia. Advances in Economics, Business and Management Research, Proceedings of the International Conference on Management, Accounting, and Economy (ICMAE 2020) 151(June 2017), 326330. https://doi.org/10.2991/aebmr.k.200915.073

Fitriani, R., Suwendra, I. W., \& Yulianthini, N. N. (2016). Analisis Financial Distress dengan Menggunakan Metode Altman Z-Score, Springate, dan Zmijewski pada perusahaan Telekomunikasi. Jurnal Manajemen Indonesia, 4(1).

Gelman, A. (2017). What's the Point of a Robustness Check? 04 21, 2021, dari Statistica Modeling, Casual Inference, and Social Science. (http//andrewgelman.com/2017/11/29/whats-pointrobusness-check/, diakses 21 April 2021)

Gunawan, B., Rahadien, P., \& Desi, S. (2017). Perbandingan Prediksi Financial Distress dengan Model Altman, Grover, dan Zmijewski. Akuntansi dan Investasi, 119-127.

Hastuti, R. T. (2018). Analisis Komparasi Model Prediksi Financial Distress Altman, Springate, Grover dan Ohlson pada Perusahaan Manufaktur yang Terdaftar di Bursa Efek Indonesia Periode 2011-2013. Jurnal Ekonomi, 20(3), 446. https://doi.org/10.24912/je.v20i3.405

Huda, E. N. (2017). Analisis Financial Distress dengan Menggunakan Model Altman, Springate dan Zmijewski pada Perusahaan Retail yang Terdaftar di BEI Tahun 2013-2017. Journal of Management: Jurnal Ilmiah Mahasiswa S1 Manajemen Universitas Pandanaran 1-11.

Hungan, A. G. D., \& Sawitri, N. N. (2018). Analysis of Financial Distress with Springate and Method of Grover in Coal in BEI 2012 - 2016. International Business and Accounting Research Journal, 2(2), 52. https://doi.org/10.15294/ibarj.v2i2.39

Ick, F. J., \& Tarigan, L. (2018). Analisis Perbandingan Model Altman Z-Score, Model Zmijewski, Model Springate, dan Model Grover dalam Memprediksi Kebangkrutan pada Perusahaan 
Inggar Nur Arini. Analisi Akurasi Model-Model Prediksi Financial Distress

Pertambangan di BEI (periode 2012-2016). Fundamental Management Journal, 3(1), 44-53. http://ejournal.uki.ac.id/index.php/jm/article/view/720

Kartikasari, \& Hariyani, D. S. (2019). Ketepatan Model Prediksi Financial Distress pada Perusahaan Retail di Indonesia. Jurnal Nusantara Aplikasi Manajemen Bisnis, 4(2), 117-127. https://doi.org/10.29407/nusamba.v4i2.12651

Kim, Y. (2020). The Running List of 2020 Retail Bankruptcies. Retaildive. (https://www.retaildive.com/news/the-running-list-of-2020-retail-bankruptcies/571159/, diakses tanggal 30 Desember 2020)

Komarudin, Syafnita, \& Ilmiani, A. (2019). Analisis Komparasi Prediksi Financial Distress Metode Grover, Altman, Springate, Zmijewski, dan Ohlson pada Perusahaan Pertambangan di BEI. Jurnal Ekonomi dan Bisnis, 22(2), 36-43.

Meiliawati, A., \& Isharijadi, I. (2017). Analisis Perbandingan Model Springate dan Altman Z Score Terhadap Potensi Financial Distress (Studi kasus pada perusahaan sektor osmetik yang terdaftar di Bursa Efek Indonesia). Assets: Jurnal Akuntansi dan Pendidikan, 5(1), 15. https://doi.org/10.25273/jap.v5i1.1183

Najib, A. S., \& Cahyaningdyah, D. (2020). Analysis of The Bankruptcy of Companies with Altman Model and Ohlson Model. Management Analysis Journal, 9(3), 243-251. https://doi.org/10.15294/maj.v9i3.37797

Parquinda, L., \& Azizah, D. F. (2019). Analisis Penggunaan Model Grover (G-Score), Fulmer (HScore), Springate (S-Score), Zmijewski (X-Score), dan Altman (Z-Score) sebagai Prediktor Kebangkrutan (Studi pada Perusahaan Tekstil dan Garmen yang listing di Bursa Efek Indonesia (BEI) Periode 2015-2. Jurnal Administrasi Bisnis (JAB), 72(1), 110-118.

Primasari, N. S. (2018). Analisis Altman z-Score, Grover Score, Springate, Dan Zmijewski Sebagai Signaling Financial Distress (Studi Empiris Industri Barang-Barang Konsumsi di Indonesia). Accounting and Management Journal, 1(1), 23-43. https://doi.org/10.33086/amj.v1i1.70

Priyanti, M. W. A. (2019). Analisis metode Altman Z-Score, Springate, dan Zmijewski untuk Memprediksi Financial Distress. Jurnal Ilmu dan Riset Akuntansi, 8(6), 1-15.

Putri, D. P. S. (2018). Comparison of bankruptcy Prediction Models Analysis (Altman, Springate, Grover, Ohlson and Zmijewski) on PT. Asuransi Harta Aman Pratama, Tbk. Economics \& Accounting Journal, 1(2), 156. https://doi.org/10.32493/eaj.v1i2.y2018.p156-165

Ratri, A. M. (2020). Model Prediktor Potensi Kesulitan Keuangan. Jurnal Bisnis dan Manajemen, $7(1), 46-54$.

Sari, R. P. (2016). Analisis Perbandingan Model Altman, Springate dan Zmijewski dalam Memprediksi Kebangkrutan. Jurnal of Accounting and Financial, 33-41.

Susanti. (2016). Analisis Kebangkrutan dengan Menggunakan Metode Altman Z Score, Springate, dan Zmijewski. Jurnal Aplikasi Manajemen, 14, 802-806.

Tan, E., \& Wibisana, T. A. (2020). A Comparative Analysis Altman (Z-Score) Revision and Springate (S-Score) Model in Predicting Financial Distress in the Manufacturing CompanyIndonesia Stock Exchange. Journal of Reseach in Business, Economics, and Education, 2(4), 832-841.

Vestari, M., \& Farida, D. N. (2014). Analisis Rasio-Rasio dan Ukuran Keuangan, Prediksi Financial 
Distress, dan Reaksi Investor. AKRUAL: Jurnal Akuntansi, 5(1), 26. https://doi.org/10.26740/jaj.v5n1.p26-44

Winaya, G. Y., Rm, K. M., Budiasih, I. G. A. N., \& Wiratmaja, I. D. N. (2020). Analysis of Altman Z-Score and Zmijewski Bankruptcy Prediction in Telecommunication Sub-Sectors Registered in Indonesia Stock Exchange in 2016-2018. American Journal of Humanities and Social Sciences Research, 4(1), 313-322.

Zebua, D., \& Purnomo, H. (2020). Prediksi Financial Distress Menggunakan Model Zmijewski, Springate dan Grover pada Perusahaan Agrikultur yang Terdaftar di Bursa Efek Indosenia Periode 2014-2018. Equilibrium Jurnal Bisnis\& Akuntansi, XIV(1), 31-39. 